\title{
Preparation and Properties of a New Carbon Paste Iron Selective Electrodes and Their Applications
}

\author{
Refat F. Aglan ${ }^{1 *}$, Mahmoud S. Rizk ${ }^{2}$, Gehad G. Mohamed ${ }^{2}$, \\ Ahmed H. El-Wahy ${ }^{2}$, Hala A. Mohamed ${ }^{3}$ \\ ${ }^{1}$ Hot Laboratory Center, Atomic Energy Authority, Cairo, Egypt \\ ${ }^{2}$ Chemistry Department, Faculty of Science, Cairo University, Giza, Egypt \\ ${ }^{3}$ Chemistry Administration, Cairo, Egypt \\ Email: *refatfekry_aglan@yahoo.com
}

Received November 27, 2013; revised December 28, 2013; accepted January 9, 2014

Copyright (C) 2014 Refat F. Aglan et al. This is an open access article distributed under the Creative Commons Attribution License, which permits unrestricted use, distribution, and reproduction in any medium, provided the original work is properly cited. In accordance of the Creative Commons Attribution License all Copyrights @ 2014 are reserved for SCIRP and the owner of the intellectual property Refat F. Aglan et al. All Copyright (C) 2014 are guarded by law and by SCIRP as a guardian.

\section{ABSTRACT}

The new ferrous-selective modified carbon paste electrodes (I and II) based on 5,5'-(propane-1,3-diyl-bis(sulfanediyl))bis(3-benzyl-4H-1,2,4-triazol-4-amine) (electrode I, A-ionophore) and 5,5'-(butane-1,4-diyl-bis(sulfanediyl))bis(3-benzyl-4H-1,2,4-triazol-4-amine) (electrode II, B-ionophore) as ionophores are described. These electrodes exhibit Nernstian slopes of $30.2 \pm 0.5$ and $29.1 \pm 0.5 \mathrm{mV} \cdot$ decade $^{-1}$, linear range of $1.0 \times 10^{-7}-1.0 \times 10^{-2}$ $\mathrm{mol} \cdot \mathrm{L}^{-1} \mathrm{Fe}(\mathrm{II})$ ion and detection limit of $1.0 \times 10^{-7} \mathrm{~mol} \cdot \mathrm{L}^{-1} \mathrm{Fe}(\mathrm{II})$ ion for electrode (I) and electrode (II), respectively. Both electrodes (I and II) have a fast response time of about 15 sand can be used for at least 3 months. The two electrodes revealed a good selectivity for $\mathrm{Fe}$ (II) over a wide variety of other metal ions and could be used in the $\mathrm{pH}$ range of 1.8 - 3.0 without any divergence in potential. The proposed sensors were successfully applied for the determination of $\mathrm{Fe}(\mathrm{II})$ ion in different real samples.

\section{KEYWORDS}

Triazol Ionophores; Ferrous Ion Determination; Modified Carbon Paste Electrodes

\section{Introduction}

Iron is an important element in environmental, industrial and medical applications and in biological studies [1]. It presents in a variety of rock and soil minerals in oxidation states 2 and 3 [2]. However, $\mathrm{Fe}(\mathrm{II})$ and $\mathrm{Fe}(\mathrm{III})$ play different major roles in the biosphere. It is widely accepted that the presence of iron, alone or in combination, has beneficial or deleterious effects on the properties of many substances and the nature of various biological systems. It plays an important role in oxygen and electron transport; provides a fundamental structure of hemoglobin, myoglobin, hemenzymes and many co-factors involved in enzyme activities [3]. In the industrialized world, the iron is the first metal in its usage, and its compounds can justifiably be said to touch our daily lives.

${ }^{*}$ Corresponding author.
For the human body and other high animals, Fe(II) is not only a key element in energy metabolism, but also crucially important in the transport and storage oxygen in higher animals while $\mathrm{Fe}(\mathrm{III})$ was not binding to oxygen [4]. Iron element is crucially important to human health. However, iron deficiency anemia is one of the world's most common nutritional deficiency diseases [5]. Ferrous iron in food and pharmaceuticals could be directly assimilated, while ferric iron must be done after being reduced to ferrous [6]. The importance of $\mathrm{Fe}(\mathrm{II})$ in food and pharmaceuticals has sustained an intense interest in the development of selective method determination for $\mathrm{Fe}(\mathrm{II})$. Although there are a number of papers that deal with the total iron in the real samples, only a few have reported the concentration of Fe(II). Recently, analytical techniques developed and described Fe(II) determinations including electron spin resonance method (the method is very expensive and inconvenient in operation) [7], 
UV-vis spectrometry [8,9], controlled-potential coulometry [10], high-performance liquid chromatographic method [11] and luminescence analysis [12], capillary electrophoresis [13], fluorometric analysis method [14, 15]. Though these methods provide accurate results, but they are not very convenient for the analysis of a large number of environmental samples as they require sample pretreatment and sufficient infrastructure back-up. On the other hand, analytical procedures involving ion sensors are most appropriate for such determinations as they require no or minimum sample pretreatment and are fast, convenient and cheap. Of course analysis by ion sensor requires the availability of sensitive and selective iron sensor. However, these methods require large infrastructure and are too expensive for most analytical laboratories. Thus, much attention has been drawn on developing a convenient method to determine $\mathrm{Fe}(\mathrm{II})$ ion.

Electrochemical technique has proven to be a very useful and versatile tool in metal ion speciation, since it makes it possible to distinguish between free and bound ions, as well as their oxidation states [16]. In addition, the sensitivity of the techniques is a very useful feature, because the concentration range to detect the chemical species varies between 1 and up to $1 \times 10^{-10} \mathrm{~mol} \cdot \mathrm{L}^{-1}$ and even lower concentration, for some inorganic, metalorganic, and organic species [17]. Carbon paste electrodes (CPEs) in combination with the suitable electrochemical technique have been shown to be widely applicable in studying heavy metals [18]. The advantages of using CPEs include the fact that they are inexpensive, easy to prepare, they offer a wide potential window and a low background current and in addition, it is easy to modify the electrode with different organic, inorganic, and biological products with the aim of increasing their sensitivity and selectivity in order to determine heavy metals $[19,20]$. In the present work, ferrous carbon paste ion selective electrodes are constructed and their performance characteristics are investigated. The electrodes are based on incorporation of the A and B ionophores in a carbon paste plasticized with different plasticizers. The electrodes are used successfully as sensors to determine iron in different pharmaceutical samples (ferro sanol duodenal, folicron and ferrofol).

\section{Experimental}

\subsection{Apparatus}

All measurements were carried out at room temperature $25^{\circ} \mathrm{C} \pm 1^{\circ} \mathrm{C}$ using a $692-\mathrm{pH}$ meter (Metrohm). A techne circulator thermostat Model C-100 (Cambridge, England) was used to control the temperature of the test solution. The potential was measured under constant stirring of the test solution with respect to a double-junction silversilver chloride reference electrode (Metrohm 6.0726.100) and iron modified carbon paste as the indicator electrode.

\subsection{Reagents}

Analytical reagent grade chemicals and doubly distilled water were used for preparing all aqueous solutions. Solutions were prepared from a stock solution of 0.01 $\mathrm{mol} \cdot \mathrm{L}^{-1} \mathrm{Fe}(\mathrm{II})$, prepared from a sufficient quantity of ferrous sulphate (Merck) in bi-distilled water. The working solutions were prepared daily by suitable dilution of stock solution. All other solutions used in interference studies were prepared from analytical grade nitrate salts (all from Merck Company). Graphite fine powder extra pure, dioctyl phthalate (DOP), dioctyl sebacate (DOS), tricresyl phosphate (TCP), o-nitrophenyloctyl ether (oNPOE) were used as received from Aldrich.

\subsection{Preparation of Ionophores}

5,5'-(propane-1,3-diylbis(sulfanediyl))bis(3-benzyl-4H-1, 2,4-triazol-4-amine) and 5,5'-(butane-1,4-diylbis(sulfanediyl))bis(3-benzyl-4H-1,2,4-triazol-4-amine) were prepared according to the method of Elwahy et al. [21,22].

\subsection{The Electrode Preparation}

The chemically modified carbon paste $\mathrm{Fe}(\mathrm{II})$ electrodes were prepared as described previously [23]. Teflon holder (12 cm length) with a hole at one end $(7 \mathrm{~mm}$ diameter and $3.5 \mathrm{~mm}$ deep) for the carbon paste filling was served as the electrode body. Electrical contact was made with a stainless steel rod through the center of the holder. This rod can move up and down by screw movement to press the paste down when renewal of the electrode surface is needed. Carbon paste was prepared by thoroughly mixing $20 \mathrm{mg}$ of 5,5'-(butane-1,4-diylbis(sulfanediyl))bis(3benzyl-4H-1,2,4-triazol-4-amine) (ionophore A) or 5,5'(propane-1,3-diylbis(sulfanediyl))bis(3-benzyl-4H-1,2,4triazol-4-amine) ((ionophore B) with graphite powder (500 mg) and different plasticizers (0.2 $\mathrm{ml}$ of DOP, TCP, DOS or $o$-NPOE). Very intimate homogenization is then achieved by careful mixing using agate pestle and mortar and afterwards rubbed by intensive pressing with the pestle. The ready prepared paste is then packed into the hole of the electrode bodies and the carbon paste was smoothed onto a wet filter paper until it had a shiny appearance. After several times of use, a fresh electrodes surface can be obtained by squeezing out a small amount of the paste, scrapping off the excess against a conventional paper and polishing the electrode on a smooth paper to obtain a shiny appearance again.

\subsection{Potential Measurements}

All measurements were carried out in a $50 \mathrm{ml}$ double walled glass cell, with constant magnetic stirring of the 
test solution at room temperature. The performance of the electrodes was investigated by measuring the emf of ferrous sulphate solutions prepared with a concentration range of $10^{-2}$ to $10^{-7} \mathrm{~mol} \cdot \mathrm{L}^{-1}$ by serial dilution. The emf was plotted as a function of $\log [\mathrm{Fe}(\mathrm{II})]$. The detection limit was taken at the point of intersection of the extrapolated linear segments of the calibration curve. The selectivity coefficients $\left(\mathrm{K}_{\mathrm{Fe}, \mathrm{J}}^{\mathrm{pot}}\right)$ were measured using the separate solutionand matched potential methods using $0.01 \mathrm{~mol} \cdot \mathrm{L}^{-1} \mathrm{Fe}(\mathrm{II})$ and interfering ions. The $\mathrm{pH}$ of $\mathrm{Fe}(\mathrm{II})$ solution was adjusted by adding an appropriate amount of $1 \mathrm{~mol} \cdot \mathrm{L}^{-1}$ of either nitric acid or $\mathrm{NaOH}$.

\section{Results and Discussion}

\subsection{Optimization of the Carbon Paste Electrode Composition}

Preliminary experiments were carried out to obtain optimum ionophore content (A or B ionophores) in order to get the optimum carbon paste electrodes composition. The potential responses of the most sensitive electrodes, prepared under the same experimental conditions, are shown in Figures 1(a) and (b). The optimized carbon paste electrodes were used to test the performance of

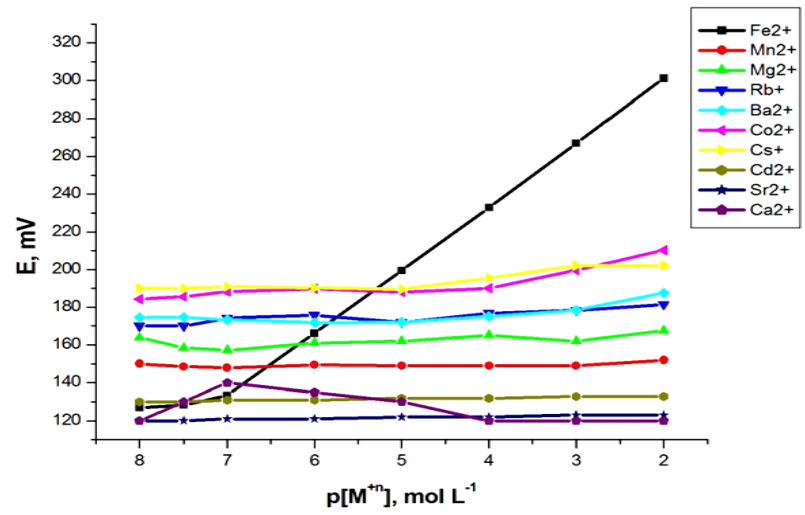

(a)

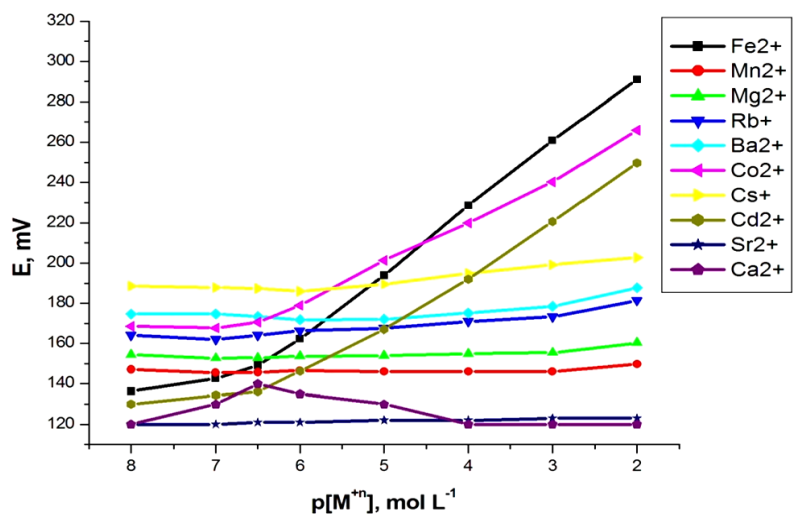

(b)

Figure 1. Calibration graphs of some inorganic cations using (a) Electrode (I); (b) Electrode (II). both carbon paste characteristics. In the presence of the proposed modified electrodes, the optimized carbon paste demonstrated a Nernstian response and remarkable selectivity for ferrous ion over several common inorganic ions. Thus, these electrodes compositions were used for subsequent studies. The potential response of the optimized $\mathrm{Fe}(\mathrm{II})$ ions was examined. The average slope of the calibration plot was $30.2 \pm 0.5$ and $29.1 \pm 0.5 \mathrm{mV} \cdot$ decade $^{-1}$ for electrodes I and II, respectively. The calibration plots are shown in Figures 2(a) and (b), which indicate that the modified sensors have linear range from $1 \times 10^{-7}$ to 1 $\times 10^{-2} \mathrm{~mol} \cdot \mathrm{L}^{-1}$ for both electrodes. The practical limit of detection, defined as the concentration of ferrous ion obtained from the intersection of two extrapolated segments of the calibration graph, was about $1.0 \times 10^{-7} \mathrm{~mol} \cdot \mathrm{L}^{-1}$ for electrodes I and II. The characteristic properties of the optimized paste are summarized in Table 1. The long term stability of the electrodes was studies by periodically recalibrating in standard solutions and calculating the

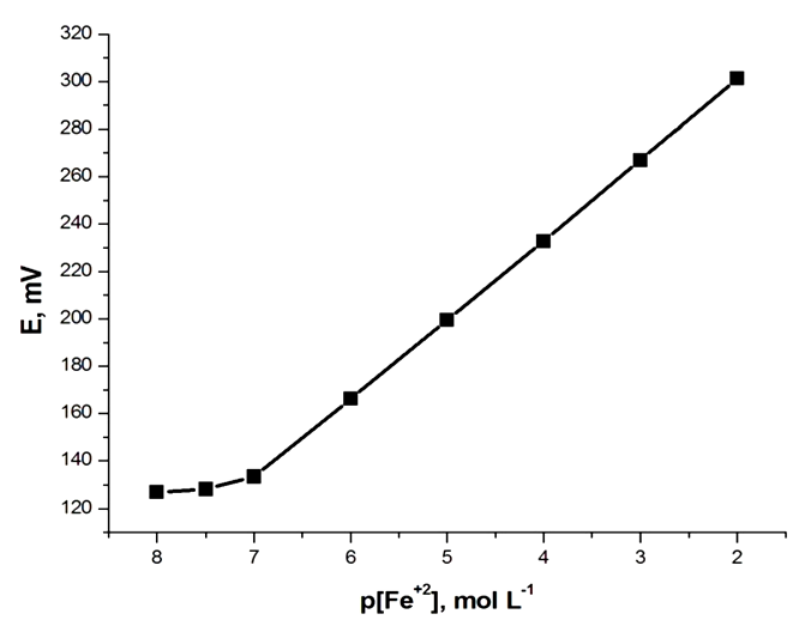

(a)

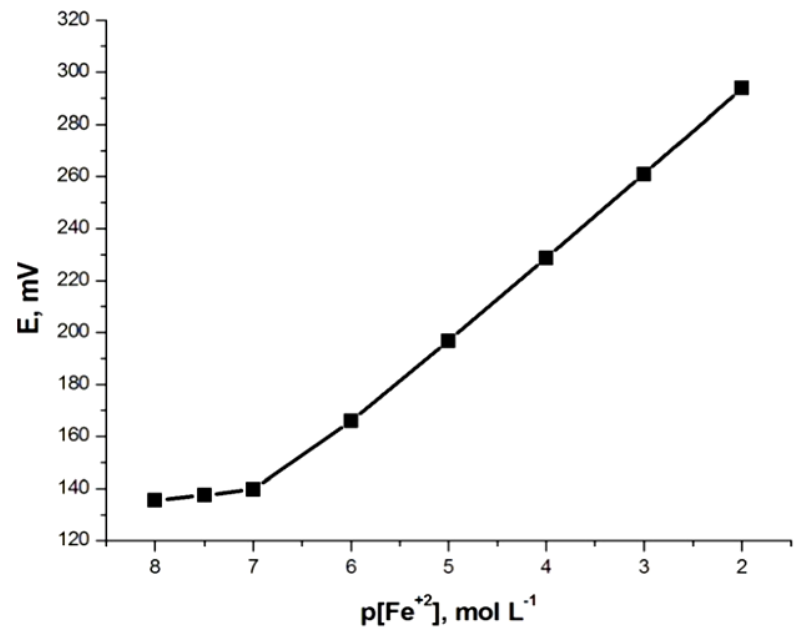

(b)

Figure 2. Potentiometric calibration response of $\mathrm{Fe}(\mathrm{II})$ electrodes: (a) Electrode (I); (b) Electrode (II). 
Table 1. Composition and response characteristics of Fe(II) carbon paste electrodes (I and II).

\begin{tabular}{|c|c|c|c|c|c|c|c|}
\hline \multirow[b]{2}{*}{ Elect. no. } & \multicolumn{3}{|c|}{ Composition, mg } & \multirow{2}{*}{$\begin{array}{l}\text { Conc. range } \\
\left(\mathrm{mol} \cdot \mathrm{L}^{-1}\right)\end{array}$} & \multirow{2}{*}{$\begin{array}{c}\text { Slope }\left(\mathrm{mV} \cdot \text { decade }^{-1} \text { ) }\right. \\
\text { A-ionophore } \\
\text { (electrode I) }\end{array}$} & \multirow{2}{*}{$\begin{array}{c}\text { Slope }\left(\mathrm{mV} \cdot \text { decade }^{-1}\right) \\
\text { B-ionophore (electrode II) }\end{array}$} & \multirow{2}{*}{$\begin{array}{l}\text { Response } \\
\text { time, s }\end{array}$} \\
\hline & $\begin{array}{l}\text { Ionophore } \\
\text { Content (mg) }\end{array}$ & $\begin{array}{c}\text { Plasticizer } \\
(100 \mu \mathrm{l})\end{array}$ & $\begin{array}{c}\text { Graphite } \\
\text { powder (mg) }\end{array}$ & & & & \\
\hline 1 & 2.5 & NPOE & 250 & $10^{-7}-10^{-2}$ & 16 & 23.7 & $<15$ \\
\hline 2 & 5 & NPOE & 250 & $10^{-7}-10^{-2}$ & 18 & 24.8 & $<15$ \\
\hline 3 & 7.5 & NPOE & 250 & $10^{-7}-10^{-2}$ & 26.5 & 25.6 & $<15$ \\
\hline 4 & 10 & NPOE & 250 & $10^{-7}-10^{-2}$ & 30.2 & 29.1 & $<15$ \\
\hline 5 & 12.5 & NPOE & 250 & $10^{-7}-10^{-2}$ & 20.5 & 24 & $<15$ \\
\hline 6 & 10 & DOP & 250 & $10^{-7}-10^{-2}$ & 22.3 & 27.5 & $<15$ \\
\hline 7 & 10 & DOS & 250 & $10^{-7}-10^{-2}$ & 27 & 23 & $<15$ \\
\hline 8 & 10 & ТСР & 250 & $10^{-7}-10^{-2}$ & 25.2 & 23 & $<15$ \\
\hline
\end{tabular}

response slope over the range of $10^{-7}-10^{-2} \mathrm{~mol} \cdot \mathrm{L}^{-1}$. The detection electrodes were very stable and could be used over a period of at least 3 months (Figure 3).

\subsection{Effect of $\mathrm{pH}$}

The potentiometric response of the electrodes was found to be sensitive to $\mathrm{pH}$ changes. The effect of $\mathrm{pH}$ on the electrodes performance was examined over the $\mathrm{pH}$ range of $1-5$ at $1 \times 10^{-2}$ and $1 \times 10^{-5} \mathrm{~mol} \cdot \mathrm{L}^{-1}$ concentration of $\mathrm{Fe}(\mathrm{II})$ and the results are shown in Figures 4(a) and (b). As can seen, the potentials are independent of $\mathrm{pH}$ in the range of 1.8 - 3 where the potential did not vary by more than $\pm 1 \mathrm{mV}$. The significant effect of $\mathrm{pH}$ on the electrode potential at $\mathrm{pH}<1.8$ and $\mathrm{pH}>3$ is attributed to a slow rate of complex formation between iron(II) and ionophores (A) or (B) and the sensors may also be exhibiting an interference effect due to hydrogen ions at low $\mathrm{pH}$. Whilst at $\mathrm{pH}$ values higher than 3 , this can be attributed to the instability of both ionophores (A and B) [24].

\subsection{Electrode Selectivity}

One of the most important characteristic of a carbon paste electrode was its response to the target ion to be measured over other ions and species present in the solution. This characteristic was expressed in terms of the potentiometric-selectivity coefficient. In this study, potentiometric-selectivity coefficients for somecations tested were determined by separate solution method (SSM) [25]. It is calculated as:

$$
\log K_{\mathrm{A}, \mathrm{B}}^{\mathrm{pot}}=\left[\left(E_{\mathrm{B}}-E_{\mathrm{A}}\right) / S\right]-\log a_{\mathrm{A}}+\left[Z_{\mathrm{A}} / Z_{\mathrm{B}}\right] \log a_{\mathrm{B}}
$$

$E_{\mathrm{A}}$ and $E_{\mathrm{B}}$ mean the potentiometric response of $a_{\mathrm{A}}$ and $a_{\mathrm{B}}$, respectively. $a_{\mathrm{A}}$ is the primary ion activity and $a_{\mathrm{B}}$ is the activity of an interfering ion. The single ion activities were calculated by the extended Debye-Hückel equation [26]. In this work, $a_{\mathrm{A}}\left(1.0 \times 10^{-3} \mathrm{~mol} \cdot \mathrm{L}^{-1} \mathrm{Fe}(\mathrm{II})\right.$ ion $)$ and $a_{\mathrm{B}}\left(1.0 \times 10^{-3} \mathrm{~mol} \cdot \mathrm{L}^{-1}\right.$ interfering ion $)$ were used to measure the selectivity coefficients. $S$, Nernstian slope,

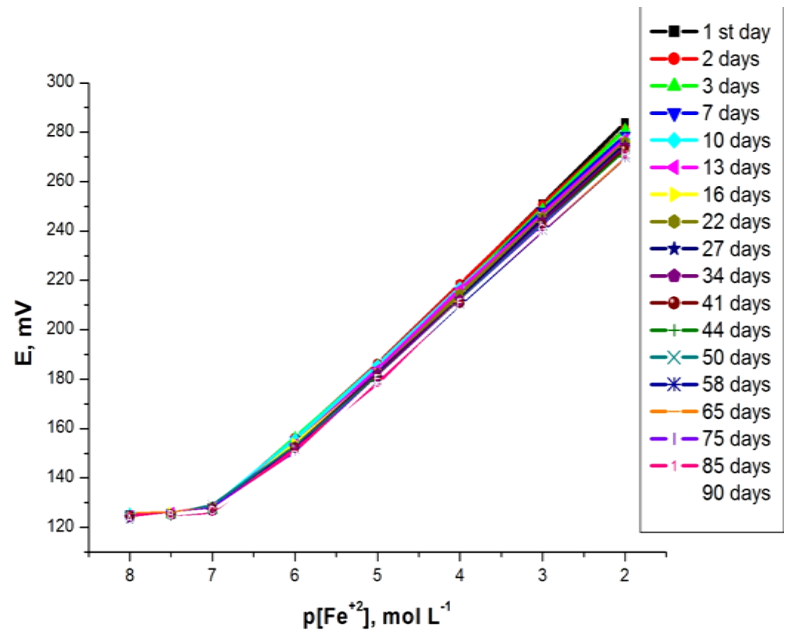

(a)

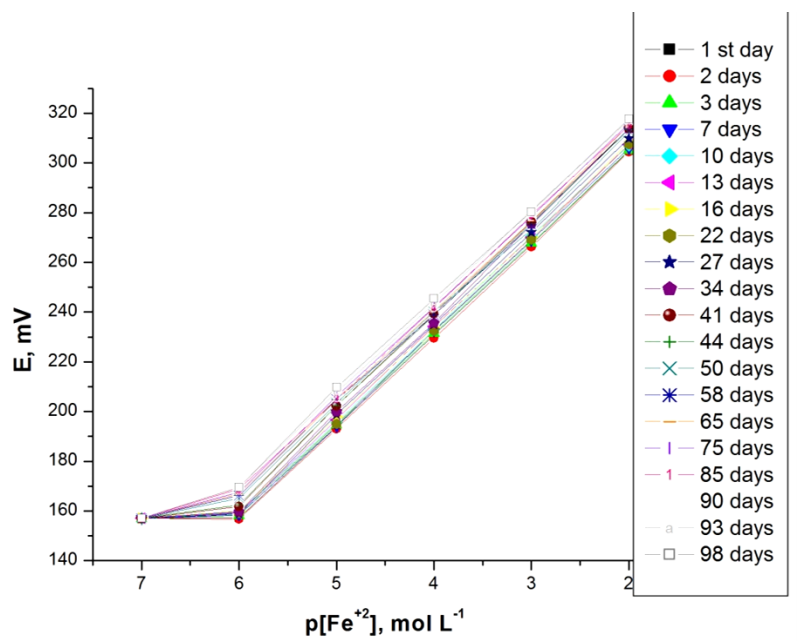

(b)

Figure 3. Life time of the Fe (II)-electrodes: (a) Electrode (I); (b) Electrode (II).

$Z_{\mathrm{A}}$ and $Z_{\mathrm{B}}$ are the charge of the primary and interfering ions, respectively. Also, matched potential method (MPM) was used to measure the selectivity coefficient. 


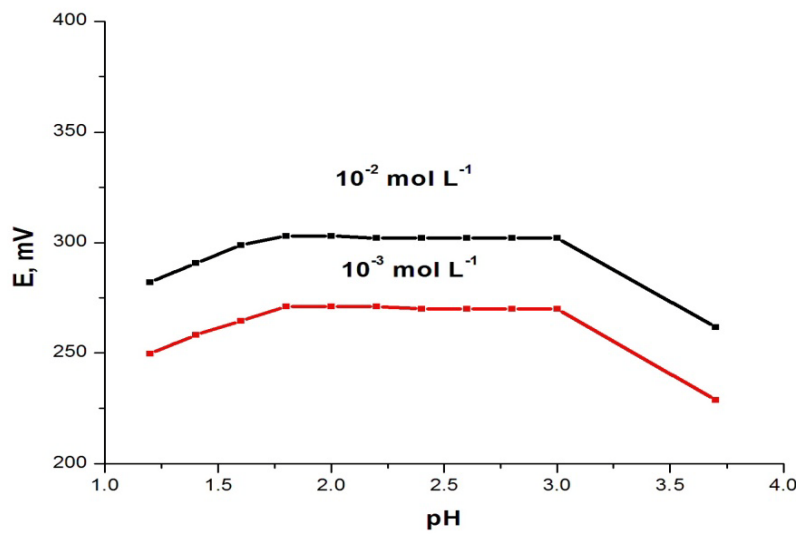

(a)

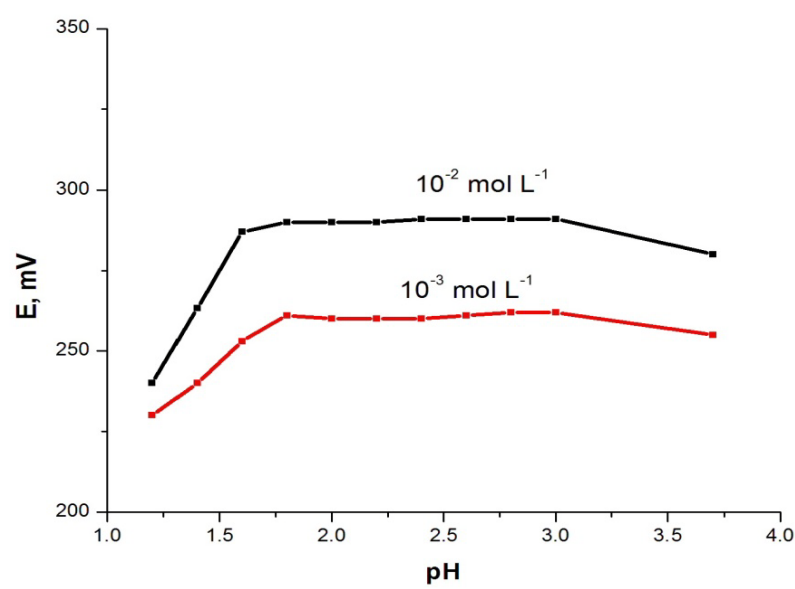

(b)

Figure 4. Effect of pH on the potentiometric response of Fe (II)-electrodes: (a) Electrode (I); (b) Electrode (II).

According to this method, the activity of Fe(II) was increased from $a_{\mathrm{A}}=1.0 \times 10^{-5} \mathrm{~mol} \cdot \mathrm{L}^{-1}$ (reference solution) to $a_{\mathrm{A}}^{\prime}=1.0 \times 10^{-3} \mathrm{~mol} \cdot \mathrm{L}^{-1}$, and the change in potential $(\Delta E)$ corresponding to this increase in activity is measured. Then, $0.1 \mathrm{~mol} \cdot \mathrm{L}^{-1}$ solution of an interfering ion is added to a new $1.0 \times 10^{-5} \mathrm{~mol} \cdot \mathrm{L}^{-1} \mathrm{Fe}(\mathrm{II})$ reference solution until the same potential change $(\Delta E)$ is recorded, the concentration of the added amount is thus $a_{\mathrm{B}}$. The selectivity coefficient $K_{\mathrm{A}, \mathrm{B}}^{\mathrm{MP}}$ for each interferent was calculated using the following equation:

$$
K_{\mathrm{A}, \mathrm{B}}^{\mathrm{pot}}=\left(a_{\mathrm{A}}^{\prime}-a_{\mathrm{A}}\right) / a_{\mathrm{B}}
$$

Possible interferences from a number of cations were studied and the results are shown in Table 2. It is obvious from Table 2 that most of the selectivity coefficients are very low, indicating no significant interference in the performance of the electrodes for determining the $\mathrm{Fe}(\mathrm{II})$ ion except for ferric ions for both ferrous electrodes (I and II) modified with ionophores (A and B). In addition, a comparative study of the response characteristics of the proposed electrodes with the reported Fe(II) ion selective electrodes based on other carriers is shown
Table 2. Potentiometric selectivity coefficient values of Fe(II) modified carbon paste electrodes (I and II).

\begin{tabular}{ccccc}
\hline \multirow{2}{*}{$\begin{array}{c}\text { Interfering } \\
\text { Species }\end{array}$} & \multicolumn{4}{c}{$\log K_{\mathrm{Fe}(\mathrm{II}) \mathrm{B}}^{\mathrm{pot}}$} \\
\cline { 2 - 5 } & \multicolumn{2}{c}{ Electrode (I) } & \multicolumn{2}{c}{ Electrode (II) } \\
\cline { 2 - 5 } $\mathrm{Na}^{+}$ & -6.47 & -6.69 & -6.05 & -6.55 \\
$\mathrm{~K}^{+}$ & -2.08 & -2.28 & -4.22 & -4.45 \\
$\mathrm{Cd}^{2+}$ & -3.54 & -3.96 & -3.15 & -3.55 \\
$\mathrm{Ni}^{2+}$ & -2.98 & -3.17 & -4.89 & -5.004 \\
$\mathrm{Co}^{2+}$ & -3.34 & -3.53 & -3.34 & -3.64 \\
$\mathrm{Hg}^{2+}$ & -6.49 & -6.79 & -6.59 & -6.71 \\
$\mathrm{Mn}^{2+}$ & -3.95 & -4.03 & -3.57 & -3.93 \\
$\mathrm{Cu}^{2+}$ & -5.02 & -5.41 & -6.85 & -7.05 \\
$\mathrm{Fe}^{3+}$ & -1.01 & -1.07 & -1.04 & -1.09 \\
\hline
\end{tabular}

in Table 3. The results indicate that the proposed electrodes are superior to those reported for Fe(II) ion selective electrodes with regard to the linear range, detection limit, slope and selectivity over a number of cations.

\subsection{Effect of Temperature}

Trend of changes of electrode performance with temperature, at test solution temperatures of $10^{\circ} \mathrm{C}, 20^{\circ} \mathrm{C}, 25^{\circ} \mathrm{C}$, $30^{\circ} \mathrm{C}, 40^{\circ} \mathrm{C}, 50^{\circ} \mathrm{C}$ and $60^{\circ} \mathrm{C}$ for $\mathrm{Fe}(\mathrm{II})$-selective electrodes were studied. The electrodes exhibit good Nernstian behaviour in the temperature range. The standard cell potentials $\left(E_{\text {cell }}^{0}\right)$, were determined at different temperatures from the respective calibration plots as the intercepts of these plots at $\mathrm{p}[\mathrm{Fe}]=0$, and were used to determine the thermal temperature coefficient $\left(\mathrm{d} E^{\mathrm{o}} / \mathrm{d} t\right)$ of the cell with the aid of the following equation [27],

$$
E_{\text {cell }}^{\mathrm{o}}=E_{\text {cell }}^{\mathrm{o}}\left(25^{\circ} \mathrm{C}\right)+\left[\left(\mathrm{d} E^{\mathrm{o}}\right)_{\text {cell }} / \mathrm{d} t\right](t-25)
$$

Plot of $E_{\text {cell }}^{o}$ versus $(t-25)$ produced a straight line of slope equals to 0.000616 and $0.000182 \mathrm{~V} /{ }^{\circ} \mathrm{C}$ for electrode I and II, respectively. These values are the thermal temperature coefficient of electrodes I and II, respectively. The small values of $\left(\mathrm{d} E^{\mathrm{o}} / \mathrm{d} t\right)_{\text {cell }}$ reveal the high thermal stability of the electrodes within the investigated temperature range.

\subsection{Effect of Plasticizer}

It is well established that the polarity and chemical structure of the electrode plasticizer can have a significant influence on the selectivity and dynamic response range of ISEs [28]. The properties of plasticizer can affect the dielectric constant of the mobility of the ionophores. Thus, different plasticizers (DOP, DOS, $o$-NPOE and TCP) were used in the construction of Fe(II) ion selective electrodes to figure out the plasticizer with the best 
Table 3. Comparative studies of Fe(II) selective electrode based on 1,3-bis(4-amino-5-benzyl-trizolel-3-thiol-3-yl) propane ionophore and the previously described ionophores.

\begin{tabular}{|c|c|c|c|c|c|c|}
\hline Ionophore & Slope mV/decade & $\mathrm{pH}$ range & Lifetime & $\begin{array}{l}\text { Detection limit } \\
\quad\left(\mathrm{mol} \cdot \mathrm{L}^{-1}\right)\end{array}$ & $\begin{array}{l}\text { Linear range } \\
\left(\mathrm{mol} \cdot \mathrm{L}^{-1}\right)\end{array}$ & Ref. no. \\
\hline N-phenylaza-15-crown-5 (NPA15C5) & 29.2 & $5-7$ & 2 months & $7.5 \times 10^{-7}$ & $1.0 \times 10^{-2}-1.0 \times 10^{-6}$ & [30] \\
\hline 2,4,6-tri(2-pyridyl)-1,3,5-triazine & $\begin{array}{l}31.9 \pm 0.2 \\
30.5 \pm 0.1 \\
32.1 \pm 0.5 \\
32.7 \pm 0.1\end{array}$ & $\begin{array}{c}3.1-7.2 \\
2.5-7.0 \\
2.6-7.1 \\
2.2-7\end{array}$ & 3 months & $5.5 \times 10^{-7}-10^{-2}$ & $5 \times 10^{-7}-10^{-2}$ & [3] \\
\hline 1,8-dihydroxyanthaqinone & 29.6 & $1.8-3$ & 3 months & $1.64 \times 10^{-7}$ & $10^{-7}-10^{-2}$ & This work \\
\hline
\end{tabular}

response. The carbon paste electrodes with $o-\mathrm{NPOE}$ as a solvent mediator produced the best response, as shown in Figures 5(a) and (b). The results, given in Table 1, indicate that sensors no. 4 (electrode I and II), composed of $100 \mathrm{mg} o$-NPOE, $250 \mathrm{mg}$ graphite and $10 \mathrm{mg}$ ionophores (A or B), give the best sensitivity, with Nernstian slopes of $30.2 \pm 0.5$ and $29.1 \pm 0.5 \mathrm{mV} \cdot$ decade $^{-1}$ and detection limit of $1 \times 10^{-7} \mathrm{~mol} \cdot \mathrm{L}^{-1}$ for electrodes I and II, respectively, over a relatively wide dynamic range from $1.0 \times$ $10^{-7}$ to $1.0 \times 10^{-2} \mathrm{~mol} \cdot \mathrm{L}^{-1}$ of $\mathrm{Fe}(\mathrm{II})$ ions. Therefore, this composition was used to study various operation parameters of the electrodes. The electrochemical performance characteristics of these electrodes were systematically evaluated according to the IUPAC recommendations [29].

\section{Analytical Applications}

\section{Determination of Fe(II) in Pharmaceutical Preparations}

In order to test the analytical validity of this approach, the electrodes have been used for the determination of $\mathrm{Fe}(\mathrm{II})$ ion in pharmaceutical samples (ferro sanol duodenal, folicron and ferrofol). Pharmaceutical samples were prepared by dissolving one tablet of the drug in 10 $\mathrm{mL} \mathrm{HCl}$ and heated to dryness. After that, the sample was dissolved in $10 \mathrm{~mL}$ distilled water, filtered and transferred to a $25 \mathrm{~mL}$ volumetric flask and this volume was completed with distilled water. The iron concentration of the samples was potentiometrically determined with these electrodes by the calibration plot method. Iron was also determined by atomic absorption spectrometry. The results are shown in Table 4. Results from ISE and AAS were found in agreement. The low values of the standard deviation and relative standard deviation indicate the accuracy and precision of the electrodes.

\section{Method Validation}

\subsection{Linearity and Range}

The calibration graphs obtained by plotting the potential values versus the final concentration were found to be rectilinear over the concentration range cited in Figure 1.

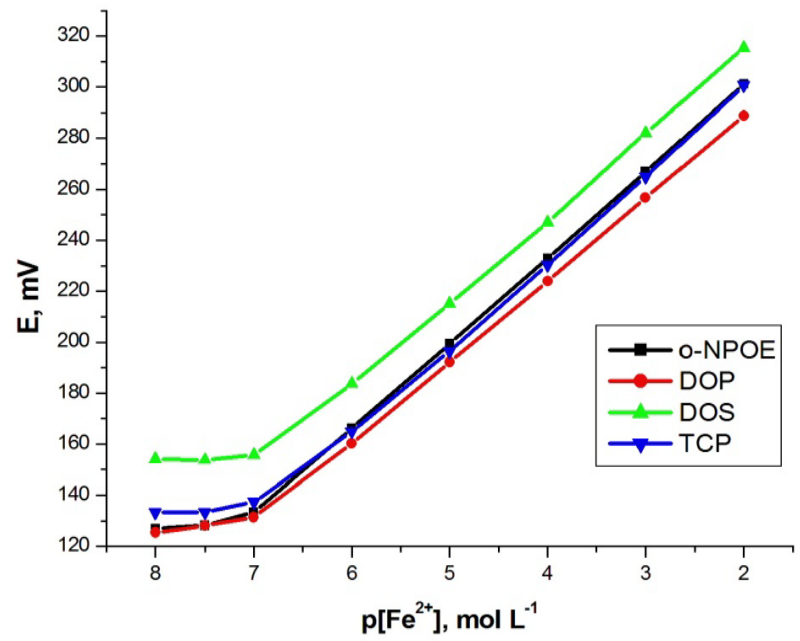

(a)

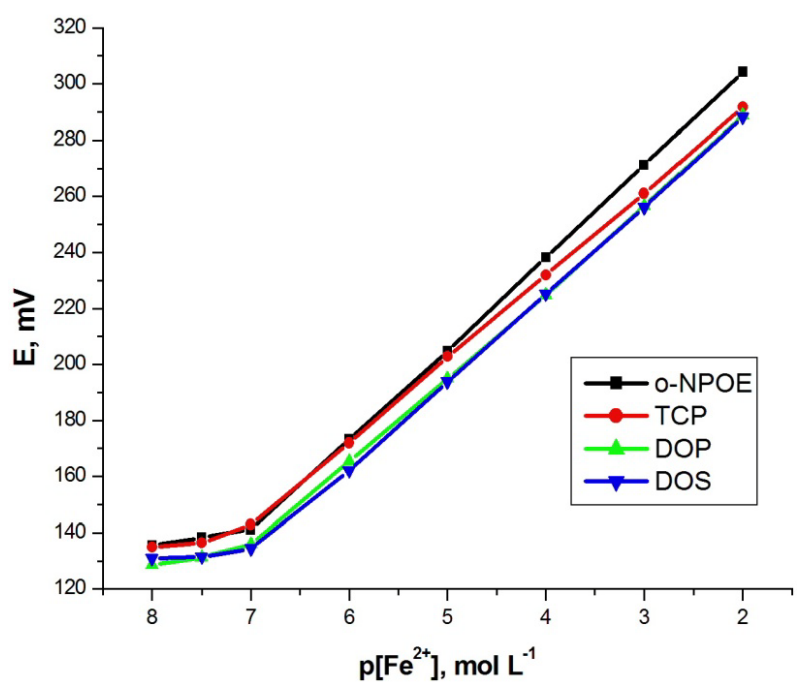

(b)

Figure 5. Effect of plasticizer on potential response of Fe (II)-electrodes: (a) Electrode (I); (b) Electrode (II).

\subsection{Limit of Quantification and Limit of Detection}

The limit of quantification (LOQ) was determined by establishing the least concentration that can be measured according to ICH Q2(R1) recommendations, below which 
the calibration range is non linear. It was found to be $4.96 \times 10^{-7}$ and $5.75 \times 10^{-7} \mathrm{~mol} \cdot \mathrm{L}^{-1}$ for electrodes I and II, respectively. The limit of detection (LOD) was determined by evaluating the lowest concentration of the $\mathrm{Fe}(\mathrm{II})$ ion analyte that can be readily detected and was found to be $1 \times 10^{-7} \mathrm{~mol} \cdot \mathrm{L}^{-1}$ for electrodes I and II, respectively. The LOQ and LOD were calculated according to the following equations (ICH 2005):

$$
\begin{aligned}
\mathrm{LOQ} & =10 S_{a} / b \\
\mathrm{LOD} & =3.3 S_{a} / b
\end{aligned}
$$

where $\left(S_{a}\right)$ is the standard deviation of the intercept of the regression line and $(b)$ is the slope of the calibration curve.

\subsection{Specificity}

The specificity of the method was investigated by ob- serving any interference encountered from the common inorganic cations (Table 2). It was found that these cations did not interfere with the results of the proposed method as shown in Table 2.

\subsection{Accuracy and Precision}

To prove the accuracy of the proposed method, the results of the assay of the studied $\mathrm{Fe}(\mathrm{II})$ in different real samples were compared with the atomic absorption method, the statistical analysis of the results using percent recovery and relative standard deviation values showed no significant differences between them regarding accuracy and precision, Table 4 for electrodes (I and II), respectively. Intra- and inter-day precisions were assessed using three concentrations and four replicates of each concentration, the relative standard deviations were found to be very small indicating reasonable repeatability of the proposed method as shown in Table 5.

Table 4. Potentiometric determination of ferrous ions in pharmaceutical formulation using CPEs (I and II) plasticized with

\begin{tabular}{|c|c|c|c|c|c|c|c|}
\hline \multirow{2}{*}{ Pharmaceutical drug } & \multirow{2}{*}{$\begin{array}{l}{[\mathrm{Fe}(\mathrm{II})] \text { Taken, }} \\
\quad \mathrm{mol} \cdot \mathrm{L}^{-1}\end{array}$} & \multicolumn{2}{|c|}{ Fe(II), \% Found } & \multicolumn{2}{|c|}{ Recovery \% } & \multicolumn{2}{|c|}{ SD, (RSD (\%)) } \\
\hline & & Calibration & AAS & calibration & AAS & calibration & ASS \\
\hline \multicolumn{8}{|l|}{ Usinf Electrode (I): } \\
\hline Ferro sanol duodenal & $1 \times 10^{-3}$ & $0.988 \times 10^{-3}$ & $0.979 \times 10^{-3}$ & 98.80 & 97.90 & $2 \times 10^{-5},(2.08)$ & $2.3 \times 10^{-5},(2.35)$ \\
\hline Ferrofol & $1 \times 10^{5}$ & $0.997 \times 10^{-3}$ & $0.989 \times 10^{-3}$ & 99.70 & 98.90 & $1.9 \times 10^{-5},(2.03)$ & $2.2 \times 10^{-5},(2.28)$ \\
\hline Folicron & & $0.987 \times 10^{-3}$ & $0.999 \times 10^{-3}$ & 98.70 & 99.90 & $2.1 \times 10^{-5},(2.17)$ & $2.3 \times 10^{-5},(2.36)$ \\
\hline \multicolumn{8}{|l|}{ Usinf electrode (II): } \\
\hline Ferro sanol duodenal & $1 \times 10^{-3}$ & $0.989 \times 10^{-3}$ & $0.979 \times 10^{-3}$ & 98.90 & 97.90 & $1.9 \times 10^{-5},(2.01)$ & $2.2 \times 10^{-5},(2.4)$ \\
\hline Ferrofol & $1 \times 10^{5}$ & $0.985 \times 10^{-3}$ & $0.987 \times 10^{-3}$ & 98.50 & 98.70 & $2.4 \times 10^{-5},(2.5)$ & $2.5 \times 10^{-5},(2.6)$ \\
\hline Folicron & & $0.996 \times 10^{-3}$ & $0.989 \times 10^{-3}$ & 99.60 & 98.90 & $2.02 \times 10^{-5},(2.08)$ & $3.2 \times 10^{-5},(3.37)$ \\
\hline
\end{tabular}
o-NPOE (n=3).

Table 5. Inter- and Intra-days precision of the determination of Fe(II) ion in pure and pharmaceutical tablet using the mod-

\begin{tabular}{|c|c|c|c|c|c|c|c|c|c|}
\hline & \multirow{2}{*}{$\begin{array}{l}\text { [Fe(II)] Taken, } \\
\mathrm{mg} \cdot \mathrm{mL}^{-1}\end{array}$} & \multicolumn{4}{|c|}{ Inter day } & \multicolumn{4}{|c|}{ Intra day } \\
\hline & & $\begin{array}{l}\text { Found, } \\
\mathrm{mg} \cdot \mathrm{mL}^{-1}\end{array}$ & $\begin{array}{c}\text { Recovery } \\
\%\end{array}$ & SD & $\begin{array}{c}\mathrm{RSD} \\
\%\end{array}$ & $\begin{array}{l}\text { Found, } \\
\mathrm{mg} \cdot \mathrm{mL}^{-1}\end{array}$ & $\begin{array}{c}\text { Recovery } \\
\%\end{array}$ & SD & $\begin{array}{c}\mathrm{RSD} \\
\%\end{array}$ \\
\hline \multicolumn{10}{|l|}{ Electorde I: } \\
\hline \multirow[b]{2}{*}{ Pure } & 0.15 & 0.149 & 99.30 & 0.022 & 1.13 & 0.1499 & 99.90 & 0.026 & 0.96 \\
\hline & 0.20 & 0.197 & 98.50 & 0.054 & 1.84 & 0.196 & 98.00 & 0.004 & 1.49 \\
\hline \multirow{3}{*}{$\begin{array}{c}\text { Ferro sanol } \\
\text { duodenal }\end{array}$} & 0.15 & 0.148 & 98.6 & 0.003 & 2.09 & 0.151 & 100.6 & 0.003 & 0.67 \\
\hline & 0.20 & 0.195 & 97.50 & 0.005 & 2.58 & 0.199 & 99.50 & 0.0021 & 1.07 \\
\hline & 0.30 & 0.297 & 99.00 & 0.004 & 1.38 & 0.299 & 99.60 & 0.006 & 2.05 \\
\hline \multirow[b]{2}{*}{ Ferrofol } & 0.15 & 0.146 & 97.30 & 0.005 & 3.33 & 0.149 & 99.30 & 0.007 & 3.53 \\
\hline & 0.20 & 0.194 & 97.00 & 0.004 & 2.02 & 0.198 & 99.00 & 0.005 & 2.52 \\
\hline \multirow{3}{*}{ Folicron } & 0.15 & 0.147 & 98.00 & 0.007 & 2.36 & 0.149 & 99.30 & 0.006 & 4.00 \\
\hline & 0.20 & 0.196 & 98.00 & 0.004 & 1.35 & 0.201 & 100.50 & 0.008 & 5.35 \\
\hline & 0.30 & 0.295 & 98.33 & 0.012 & 4.05 & 0.299 & 99.66 & 0.005 & 3.33 \\
\hline
\end{tabular}
ified CPEs (I and II). 


\section{Continued}

\begin{tabular}{|c|c|c|c|c|c|c|c|c|c|}
\hline \multicolumn{10}{|l|}{ Electrode II: } \\
\hline \multirow{3}{*}{ Pure } & 0.15 & 0.146 & 97.00 & 0.012 & 1.13 & 0.1498 & 99.80 & 0.026 & 0.94 \\
\hline & 0.20 & 0.196 & 98.00 & 0.004 & 2.04 & 0.198 & 99.00 & 0.005 & 1.48 \\
\hline & 0.30 & 0.298 & 99.00 & 0.005 & 0.615 & 0.301 & 100.30 & 0.0042 & 1.61 \\
\hline \multirow{3}{*}{$\begin{array}{c}\text { Ferro sanol } \\
\text { duodenal }\end{array}$} & 0.15 & 0.147 & 98.00 & 0.004 & 2.04 & 0.150 & 100.00 & 0.002 & 0.68 \\
\hline & 0.20 & 0.196 & 97.00 & 0.004 & 2.73 & 0.201 & 100.50 & 0.0031 & 1.09 \\
\hline & 0.30 & 0.298 & 99.30 & 0.005 & 1.39 & 0.299 & 99.60 & 0.008 & 2.15 \\
\hline \multirow{3}{*}{ Ferrofol } & 0.15 & 0.148 & 98.60 & 0.002 & 3.03 & 0.149 & 99.30 & 0.01 & 3.50 \\
\hline & 0.20 & 0.195 & 97.50 & 0.003 & 2.12 & 0.199 & 99.50 & 0.007 & 2.51 \\
\hline & 0.30 & 0.294 & 98.00 & 0.009 & 5.09 & 0.31 & 103.30 & 0.003 & 0.40 \\
\hline \multirow{3}{*}{ Folicron } & 0.15 & 0.146 & 97.30 & 0.01 & 2.26 & 0.149 & 99.30 & 0.009 & 4.00 \\
\hline & 0.20 & 0.197 & 98.50 & 0.004 & 1.35 & 0.201 & 100.50 & 0.006 & 5.15 \\
\hline & 0.30 & 0.296 & 98.63 & 0.01 & 4.03 & 0.299 & 99.66 & 0.007 & 3.23 \\
\hline
\end{tabular}

\section{Conclusion}

Carbon paste electrodes were modified with 5,5'-(butane1,4-diylbis(sulfanediyl))bis(3-benzyl-4H-1,2,4-triazol-4amine) and 5,5'-(propane-1,3-diylbis(sulfanediyl))bis(3benzyl-4H-1,2,4-triazol-4-amine) and applied to the potentiometric determination of ferrousion. The calibration curves were obtained, which were linear in the iron concentration range of $10^{-7}-10^{-2} \mathrm{~mol} \cdot \mathrm{L}^{-1}$ with Nernst slopes of 30.2 and $29.1 \mathrm{mV} \cdot$ decade $^{-1}$ for electrodes I and II, respectively. The two electrodes could be used for more than three months. Before each experiment, the electrodes were polished on a soft paper to remove the polluted surfaces. Some pharmaceutical drugs were used as real samples and successfully determined using electrodes I and II. The application of the potentiometric method using the modified electrodes in the real samples gives quite satisfactory results in comparison with the AAS method. The method was validated under optimum conditions.

\section{REFERENCES}

[1] P. T. Lieu, M. Heiskala, P. A. Peterson and Y. Yang, "The Roles of Iron in Health and Disease," Molecular Aspects of Medicine, Vol. 22, No. 1-2, 2001, pp. 1-87.

[2] S. R. Taylor and S. M. Mcleeal, "The Continental Crust: Its Composition and Evolution,” Blackwell, London, 1985.

[3] W. H. Mahmoud, "Iron Ion-Selective Electrodes for Direct Potentiometry and Potentiotitrimetry in Pharmaceuticals,” Analytica Chimica Acta, Vol. 436, No. 2, 2001, pp. 199-206. http://dx.doi.org/10.1016/S0003-2670(01)00892-3

[4] J. Mortatti, F. J. Krug, L. C. R. Pessenda, E. A. G. Zagatto and S. S. Jorgensen, "Determination of Iron in Natural Waters and Plant Material with 1,10-Phenanthroline by Flow Injection Analysis,” Analyst, Vol. 107, No. 1275, 1982, pp. 659-663.

http://dx.doi.org/10.1039/an9820700659
[5] Z. T. Zeng and R. A. Jewsbury, "Fluorimetric Determination of Iron Using 5-(4-Methoxyphenylazo)-8-(4-toluenesulfonamido)quinoline,” Analyst, Vol. 125, No. 9, 2000, pp. 1661-1665. http://dx.doi.org/10.1039/b004231p

[6] Q. Chen, “Microelements and Health,” Peking University Press, Beijing, 1989, p. 132.

[7] A. V. Kozlov, D. Y. Yegorov, Y. A. Vladimirov and O. A. Azizova, "Intracellular Free Iron in Liver Tissue and Liver Homogenate: Studies with Electron Paramagnetic Resonance on the Formation of Paramagnetic Complexes with Desferal and Nitric Oxide,” Biology and Medicine, Vol. 13, No. 1-2, 1992, pp. 9-16. http://dx.doi.org/10.1080/03630260701699821

[8] Z. O. Tesfaldet, J. F. Van Staden and R. I. Stefan, "Sequential Injection Spectrophotometric Determination of Trace Amounts of Iodide by Its Catalytic Effect on the 4,4'-Methylenebis(N,N-dimethylaniline)-chloramine-T-Reaction,” Talanta, Vol. 64, No. 5, 2004, pp. 1189-1195. http://dx.doi.org/10.1016/j.talanta.2004.04.038

[9] A. Huberman and C. Perez, "Nonheme Iron Determination,” Analytical Biochemistry, Vol. 307, 2002, pp. 375378.

[10] T. D. Waite and F. M. Morel, "Coulometric Technique for Studying the Redox Dynamics of Iron in Seawater," Analytical Chemistry, Vol. 56, No. 4, 1984, pp. 787-792. http://dx.doi.org/10.1021/ac00268a045

[11] Z. Yi, G. Zhuang, P. R. Brown and R. A. Duce, "HighPerformance Liquid Chromatographic Method for the Determination of Ultratrace Amounts of Iron(II) in Aerosols, Rainwater, and Seawater," Analytical Chemistry, Vol. 64, No. 22, 1992, pp. 2826-2830. http://dx.doi.org/10.1021/ac00046a028

[12] P. L. Croot and P. Laan, "Continuous Shipboard Determination of $\mathrm{Fe}(\mathrm{II})$ in Polar Waters Using Flow Injection Analysis with Chemiluminescence Detection,” Analytica Chimica Acta, Vol. 466, No. 2, 2002, pp. 261-273. http://dx.doi.org/10.1016/S0003-2670(02)00596-2

[13] J. Xu, P. Che and Y. F. Ma, "More Sensitive Way to Determine Iron Using an Iron(II)-1,10-phenanthroline Complex and Capillary Electrophoresis,” Journal of Chromatography A, Vol. 749, No. 1-2, 1996, pp. 287-294. 
http://dx.doi.org/10.1016/0021-9673(96)00457-8

[14] G. H. Zhu, Z. C. Zhu and L. F. Qiu, "A Fluorometric Method for the Determination of Iron(II) with Fluorescein Isothiocyanate and Iodine," Analytical Sciences, Vol. 18, No. 9, 2002, pp. 1059-1061. http://dx.doi.org/10.2116/analsci.18.1059

[15] S. Y. Bao, G. H. Wang, B. S. Liu, H. Sun, Y. Huang and S. Shi, Chinese Journal of Spectroscopy and Spectral Analysis, Vol. 1, 2001, p. 87.

[16] I. G. Švegl and B. Ogorevc, "Soil-Modified Carbon Paste Electrode: A Useful Tool in Environmental Assessment of Heavy Metal Ion Binding Interactions," Journal of Analytical Chemistry, Vol. 367, No. 8, 2000, pp. 701-706.

[17] P. M. Bersier, J. Howell and C. Bruntlett, "Advanced Electroanalytical Techniques versus Atomic Absorption Spectrometry, Inductively Coupled Plasma Atomic Emission Spectrometry and Inductively Coupled Plasma Mass Spectrometry in Environmental Analysis,” Analyst, Vol. 119, No. 2, 1994, pp. 219-232.

http://dx.doi.org/10.2116/analsci.18.1059

[18] I. Svancara, K. Vytras, K. Kalcher, A. Walcarius and J. Wang, "Carbon Paste Electrodes in Facts, Numbers, and Notes: A Review on the Occasion of the 50-Years Jubilee of Carbon Paste in Electrochemistry and Electroanalysis,” J. Electroanalysis Vol. 21, No. 1, 2009, pp. 7-28. http://dx.doi.org/10.1002/elan.200804340

[19] M. J. Gismera, D. Hueso, J. R. Procopio and M. T. Sevilla, "Ion Selective Carbon Paste Electrode Based on Tetraethyl Thiuram Disulfide for Copper(II) and Mercury (II),” Analytica Chimica Acta, Vol. 524, No. 1-2, 2004, pp. 347-353. http://dx.doi.org/10.1016/j.aca.2004.03.098

[20] C. Thobie-Gautier, W. T. Lopes da Silva, M. O. O. Rezende and N. E. Murr, "Sensitive and Reproducible Quantification of Cupper by Stripping with a Carbon Paste Electrode Modified with Humic Acid,” Journal of Environmental Science and Health, Part A, Vol. 38, No. 9, 2003, pp. 1811-1823. http://dx.doi.org/10.1081/ESE-120022880

[21] A. H. M. Elwahy, A. A. Abbas and Y. A. Ibrahim, "Synthesis of New Dibenzo Nitrogen-Oxygen-Sulfur Macrocucles Containing Two Triazole Rings," Journal of Chemical Research, No. 4, 1996, pp. 182-183.

[22] A. H. M. Elwahy, A. A. Abbas and R. M. Kassab, "Synthesis of Novel Macrocyclic Di-and Tetralactams Con- taining Triazole Subunits," Heteroatom, Vol. 14, No. 6, 2003, pp. 551-559. http://dx.doi.org/10.1002/hc.10191

[23] R. F. Aglan, G. G. Mohamed and H. A. Mohamed, "Chemically Modified Carbon Paste Electrode for Determination of Cesium Ion by Potentiometric Method," American Journal of Analytical Chemistry, Vol. 3, No. 8, 2012, pp. 576-586. http://dx.doi.org/10.4236/ajac.2012.38076

[24] J. Jezek, J. W. Dilleen, B. G. D. Haggett, A. G. Fogg and B. J. Birch, "Hexacyanoferrate(III) as a Mediator in the Determination of Total Iron in Potable Waters as Iron(II)1,10-Phenanthroline at A Single-Use Screen-Printed Carbon Sensor Device," Talanta, Vol. 71, No. 1, 2007, pp. 202-207. http://dx.doi.org/10.1016/j.talanta.2006.03.051

[25] A. Abbaspour, A. R. Esmaeilbeig, A. A. Jarrahpour, B. Khajeh and R. Kia, "Aluminium(III)-Selective Electrode Based on a Newly Synthesized Tetradentate Schiff Base," Talanta, Vol. 58, No. 2, 2002, pp. 397-403. http://dx.doi.org/10.1016/S0039-9140(02)00290-4

[26] M. B. Saleh, S. S. M. Hassan, A. A. Abdel Gaber and N. A. Abdel Kream, "Novel Potentiometric Membrane Sensor for Selective Determination of Aluminum(III) Ions" Analytica Chimica Acta, Vol. 434, No. 2, 2001, pp. 247253.

[27] V. Babenikov, L. Bykova and L. Evsevleeva, "Aluminum-Selective Electrode,” Journal of Analytical Chemistry, Vol. 60, No. 9, 2005, pp. 866-867. http://dx.doi.org/10.1007/s10809-005-0197-4

[28] R. Eugster, T. Rosatzin, B. Rusterholz, B. Aebersold, U. Pedrazza, D. Ruegg, A. Schmid, U. E. Spichiger and W. Simon, "Plasticizers for Polymeric Liquid Membranes of Ion Selective Chemical Sensors," Analytica Chimica Acta, Vol. 289, No. 1, 1994, pp. 1-13.

http://dx.doi.org/10.1016/0003-2670(94)80001-4

[29] P. R. Buck and E. Lindner, "Recommendations for Nomenclature of Ionselective Electrodes," Pure and Applied Chemistry, Vol. 66, No. 12, 1994, pp. 2527-2536. http://dx.doi.org/10.1351/pac199466122527

[30] M. Aghaie, M. Giahi, H. Aghaie, M. Arvand, M. Pournaghdy and F. Yavari, "New Fe(II) Ionselective Electrode Based on N-Phenylaza-15Crown5 as Neutral Carrier in PVC Matrix,” Desalination, Vol. 247, No. 1-3, 2009, pp. 346-354. http://dx.doi.org/10.1016/j.desal.2008.10.007 